UNITED STATES DEPARTMENT OF THE INTERIOR

GEOLOGICAL SURVEY
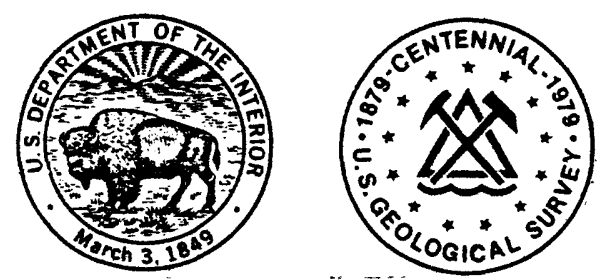

COAL DEPOSITS OF THE HEDSTROM LAKE AREA, MCCONE, GARFIELD,

PRAIRIE, CUSTER, AND ROSEBUD COUNTIES, MONTANA

By

Herbert Wincentsen

Open-File Report 79-1578

1979

This report has not been edited for conformity with U.S. Geological Survey editorial standards or stratigraphic nomenclature. 
Abstract-

Introduction-_- 1

Location and accessibility- 1

Previous investigation- 1

Present investigation-_- 2

Geography-_ 2

Topography and drainage-1 2

Economy, climate, and vegetation- 5

Stratigraphy- 5

Structure-- 5

Coal- 6

References- 7

ILLUSTRATIONS

[Plates in pocket]

Plate 1. Structure-contour map of the top of the $S$ bed or first $S$ bench; location map of correlation diagrams $A-A^{\prime}, B-B^{\prime}, C-C^{\prime}$.

2. Correlation diagrams $A-A^{\prime}, B-B^{\prime}$, and $C-C^{\prime}$.

3. Isopach map of $R$ bed or first $R$ bench; isopach map of Rogers bed or first Rogers bench; isopach map of. interburden between Rogers bed or first Rogers bench and $R$ bed or first $R$ bench.

4. Total coal isopach map of Haughins bed; isopach map of interburden between Haughins bed or first Haughins bench and $R$ bed or first $R$ bench.

5. Isopach map of $S$ bed or first $S$ bènch; isopach map of interburden between $S$ bed or first $S$ bench and Haughins bed or second Haughins bench.

Figure 1. Index map showing location of the Hedstrom Lake area----

2. Index map showing previous work in the Hedstrom Lake area-- - - -

CONVERSION TABLE

\begin{tabular}{ccc}
\hline To convert & Multiply by & To obtain \\
ENGLISH UNITS & 2.54 & METRIC UNITS \\
\hline Inches & 0.3048 & Centimeters \\
Feet & 1.609 & Meters \\
Miles & Kilometers \\
\hline
\end{tabular}




\section{COAL, DEPOSITS OF THE HEDSTROM LAKE AREA, MCCONE, GARFIELD, PRAIRIE, CUSTER, AND ROSEBUD COUNTIES, MONTANA}

\section{By Herbert Wincentsen}

\section{ABSTRACT}

The Hedstrom Lake area is located on the southwestern flank of the Williston basin, which is a major structural feature in eastern Montana and western North Dakota. Locally, the rocks have a structural high in T. 12 N., R. 47 E., a structural low in T. $18 \mathrm{~N} .$, R. $46 \mathrm{E}$, , and a maximum structural relief of more than $700 \mathrm{ft}$.

The exposed rocks in most of the area are part of the Tongue River Member of the Paleocene Fort Union Formation. The Tongue River Member consists of interbedded siltstone, sandstone, shale, and coal. In ascending order, the five main or principal coaz beds are the S, Haughins, R, Q, and Rogers.

The $\mathrm{S}$ bed ranges in thickness from 0 to $11 \mathrm{ft}$. The Haughins bed is usually a single bed 2-10 ft thick; in the southern part of the area, it splits into two benches which have a total thickness of $12 \mathrm{ft}$. The $R$ bed is thin in most of the area, but in the northern part it attains a thickness of $9 \mathrm{ft.}$. The $Q$ bed occurs at about the same horizon as the Rogers bed, but the drilling control and surface mapping are insufficient for correlation. The Rogers bed has a maximum thickness of $17.1 \mathrm{ft}$ in sec. $15, \mathrm{~T} .13 \mathrm{~N} ., \mathrm{R} .47 \mathrm{E}$. , but thins rapidly to the northwest.

\section{INTRODUCTION}

\section{Location and Accessibility}

The Hedstrom Lake area is in the central part of eastern Montana in Mccone, Garfield, Prairie, Custer, and Rosebud Counties, in parts of Tps. 12-18 N., Rs. 42-47 E. (fig. 1). The area is traversed by several improved roads and many unimproved roads and trails. State Highways 200, 22, and 24 are the only paved all-weather roads in the area (pl. 1). A network of bladed dirt roads or graded graveled roads provides access throughout the rest of the area.

\section{Previous Investigation}

The coal resources of McCone County were described by Collier and Knechtel (1939), who reported on previous surface mapping of the coal deposits in McCone County. In 1968, a reconnaissance of the $\mathrm{S}$ coal bed helped determine its extent and thickness (Matson, 1970). Seventeen holes were drilled and five coal cores 
were taken to determine the quantity and quality of coal in the region. Miscellarieous Field Studies Maps MF-724 and MF-725 (McKay and Mason, 1975a, 1975b) detail the coal deposits in parts of Prairie and Custer Counties. The author (1978), using data from more than 60 drill holes, refined the subsurface information on the attitude and thickness of the coal, beds in parts of McCone and Garfield Counties. The areas covered by this previous work are outlined in figure 2.

\section{Present Investigation}

This report presents the results of a 1977 drilling program designed to obtain information on the number, distribution, structure, and thickness of coal beds in an area of about $900 \mathrm{mi}^{2}$ in eastern Montana (U.S. Geological Survey and Montana Bureau of Mines and Geology, 1978). Information from 1978 surface mapping by the author and 1:20,000 aerial photographs of the area were used to plot coal-bed outcrops and the base of the baked-and-fused rock zone representing a burned coal bed. Most of the coal outcrops were approximately located by combining structure-contour maps of the coal beds with 1:24,000 surface topographic maps; however, there are no 1:24,000 topographic maps for the area north of $47^{\circ} 15^{\prime}$ latitude and east of $106^{\circ} 15^{\prime}$ longitude, so the coal outcrops in this area were plotted using 1:250,000 topographic maps, USGS Bulletin 905 (Collier and Knechtel, 1939), or 1:24,000 color photographs. Relating these data to prior work in the area helped to establish the continuity of the coal beds and to locate more accurately the position of coal-bed outcrops. This information is important in the administration and classification of the public coal lands and provides the most current geologic interpretations for future utilization of the coal.

\section{GEOGRAPHY}

Topography and Drainage

The Hedstrom Lake area lies in the Upper Missouri Basin Broken Lands (U.S. Geological Survey, 1970, p. 61-63). It is an area of mainly tablelands with moderate relief ranging from 300 to $500 \mathrm{ft}$. The only exception to this is in the southern part of the area: In Tps. 12 and $13 \mathrm{~N} .$, Rs. 45-47 E, the MissouriYellowstone divide crosses the area, and tributaries of both the Missouri and Yellowstone Rivers drain it. In places, the crest of the divide is capped with baked or fused rock and its margins are intricately dissected by intermittent streams. 


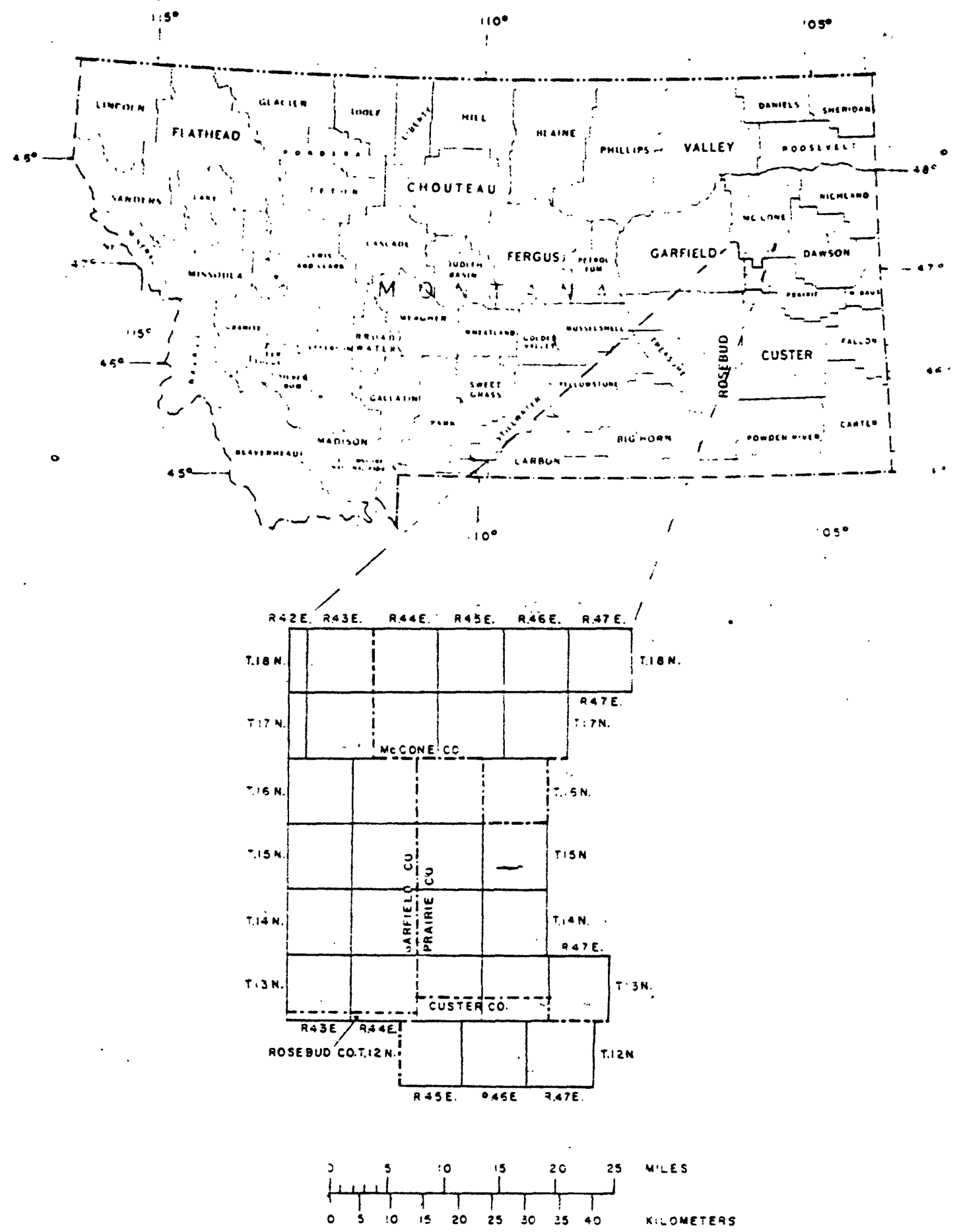

Figure 1. Index mop showing locotion of the Hedstrom Loke orea, Mc Cone, Gortield, Proirie, Rosebud, and Custer Counties, Montano 


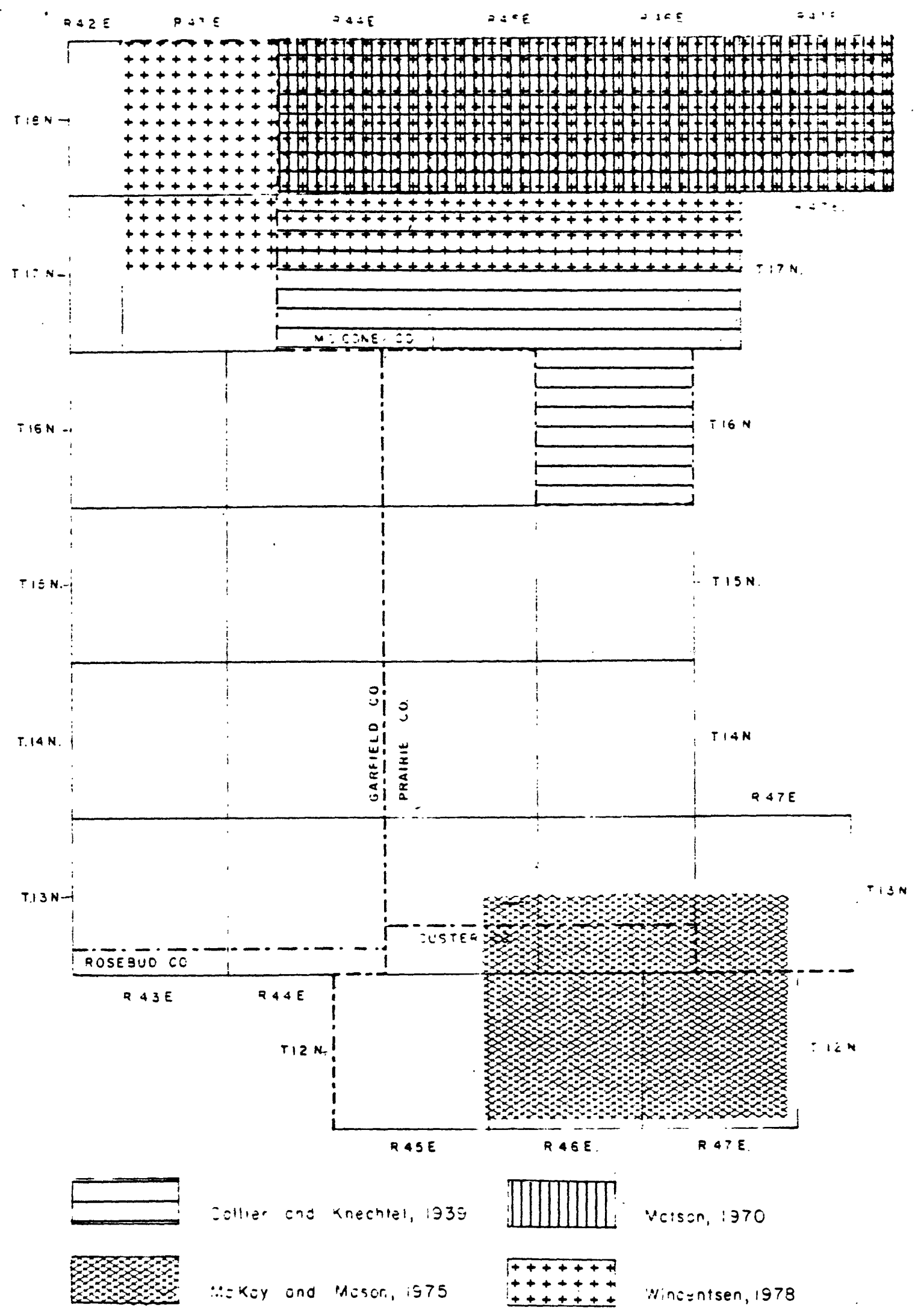

gigure? index mef sticwing grevious work ir the HEdstrom lake areo 


\section{Economy, Climate, and Vegetation}

The principal economic enterprises of the area are cattle grazing and grain production (U.S. Geological Survey, 1970, p. 170-171). The major crops are winter and spring wheat; secondary crops are mostly barley, oats, and corn.

Annual precipitation is 8-16 in., most of which occurs in June (U.S. Geological Survey, 1970, p. 97). Temperatures are moderate during the st nmer and severe during the winter.

The natural vegetation, typical of the northern plains, is mainly grama grass, needlegrass, or wheatgrass. Prickly pear cactus and yucca are also widely distributed in the area (U.S. Geological Survey, 1970, p. 90). Deciduous trees are not common in the area except along some of the intermittent streams.

\section{STRAT IGRAPHY}

Exposures in the Hedstrom Lake area consist of Tertiary sedimentary rocks and Holocene alluvial deposits.

The Tongue River Member of the Paleocene Fort Union Formation represents most of the Pertiary System in the area. It is composed of interbedded siltstone, gray or carbonaceous shale, light-yellow sandstone, and coal. Five main coal beds are present in the member. Along the south and west edges of the area the underlying Lebo Member is probably exposed.

Coal beds more than a few feet thick tend to burn along their outcrops, forming conspicuous ledges or mounds of resistant baked or fused rock. The coals in the Tongue River are generally more persistent than those in the underlying Lebo. Most coals in the Lebo, in the Hedstrom Lake area, are thin and lenticular, and even the 11-ft $U$ bed of Collier and Knechtel (1939) is not continuous for more than a few miles ( $p 1.2)$. In contrast, some beds of the Tongue River are traceable for $10-20 \mathrm{mi}$.

The alluvium is composed of silt and very fine sand; in places it includes detrital fragments of baked and fused rock. The widest belts of alluvium are . along the Little Dry Creek where they are about $1 \mathrm{mi}$ wide on each side of the stream. Narrower belts of alluvium are present along the other main streams.

\section{STRUCTURE}

Regionally, the coal field is on the southwestern flank of the Williston basin, which is the major structural feature in eastern Montana and western North Dakota (Denson and Gill, 1965, p. 26). A structure-contour map of the top of the $S$ coal bed ( $p l .1$ ) was prepared to determine the attitude of the coal beds 
in the Hedstrom Lake area. The dip of the beds is mostly north or northeast and ranges from about $20-60 \mathrm{ft} / \mathrm{mi}$.

Structurally, the highest point in the area is in sec. 32, T. $12 \mathrm{~N}$. , R. $47 \mathrm{E}$., where the elevation of the top of the $\mathrm{S}$ bed is $2,890 \mathrm{ft}$ in drill-hole US-74101. The lowest point is in sec. 6, T. $18 \mathrm{~N} .$, R. $46 \mathrm{E}$, , where the elevation of the top of the $S$ bed is less than 2,200 ft. A local depression is centered just north of the area approximately in sec. 32, T. $19 \mathrm{~N} .$, R. 46 E. (Wincentsen, 1978 , pl. 1). Therefore, the regional maximum structural relief is at least $680 \mathrm{ft}$. Some small folds are present in T. 17 N., R. 45 E., and T. 13 N., R. 45 E. COAL

Exploratory drilling indicates the presence of five main coal beds. From oldest to youngest, the beds are the $S$, Haughins, $R, Q$, and Rogers. Holes were drilled in a few thin coal beds in the Lebo Member; however, those beds were not correlated because most of the holes were not deep enough to penetrate them and because the beds were too thin or lenticular (p1. 2). The beds in the Lebo Member are referred to as "local beds" on the plates accompanying this report.

The names "Rogers" and "Haughins" are from McKay and Mason (1975a, 1975b) and the names "Q", "R", and "S" are from Collier and Knechtel (1939).

$S$ bed.--The $S$ bed is $11 \mathrm{ft}$ thick in drill-hole US-77301 in sec. 18, T. $16 \mathrm{~N}$., R. $46 \mathrm{E}$., but thins to $2 \mathrm{ft}$ or pinches out in places toward the south. In T. $18 \mathrm{~N} . ;$ R. 47 E., the bed begins to split. Farther to the east, the splitting increases, forming as many as four benches of coal (Wincentsen, 1978, p1. 8).

The $S$ bed is correlative with the Haughins no. 3 of McKay and Mason (1975a) and is sometimes correlative with Haughins no. 2 of McKay and Mason (1975b). It is currently unknown if the $S$ bed extends west of the Little Dry or Uall Creeks. Haughins bed.--The Haughins bed is generally about $60 \mathrm{ft}$ above the $S$ bed. The interburden between the two beds ranges from $5 \mathrm{ft}$ in sec. $32, \mathrm{~T} .13 \mathrm{~N}$. , R. 47 E., to more than $87 \mathrm{ft}$ in T. $17 \mathrm{~N} .$, R. $44 \mathrm{E}$. (pl. 5). The thickness of the Haughins bed ranges from $2 \mathrm{ft}$ in sec. 8 , T. $12 \mathrm{~N} ., \mathrm{R} .47 \mathrm{E}$, to $10 \mathrm{ft}$ in sec. 34 , T. $16 \mathrm{~N} .$, R. $45 \mathrm{E}$. (pl. 4). In the southeast part of the area, this bed splits into two benches separated by as much as $17 \mathrm{ft}$ in sec. $28, T .13 \mathrm{~N}:, \mathrm{R}, 47 \mathrm{E}$. The maximum total coal thickness of the split Haughins bed is $12 \mathrm{ft}$ in sec. 32, T. $13 \mathrm{~N} .$, R. 47 E. In Tps. 15 and $16 \mathrm{~N}$., Rs. 44 and $45 \mathrm{E}$., the Haughins bed has burned in many places along the outcrop, forming red hummocks of resistant, baked, overburden rock in the grassy fields. 
The Haughins bed correlates with the L2 local bed reported earlier by the author $(1978, \mathrm{pl} .4)$. In the earlier report, some of the beds in T. $18 \mathrm{~N}$. , Rs. 43-47 E., were identified as $S$ beds but they are actually the Haughins bed. $R$ bed.- The $R$ bed is about $100 \mathrm{ft}$ above the Haughins bed. McKay and Mason (1975a) referred to this bed as a local bed; however, correlations using the 1977 drilling data indicate that it is part of the $R$ bed ( $p l .3$ ). Drilling data indicate that in the northern part of the area the second $R$ bench pinches out and that the first $R$ bench may be directly correlative with the $R$ bed ( $p 1.2$ ). The $R$ bed is generally 2-4 ft thick, but in T. $18 \mathrm{~N}$. , Rs. 44-47 E., the $R$ bed, or first $R$ bench, is 5-9 ft thick. Fieldwork and aerial photography show that in most parts of the area the $R$ bed is unburned and covered.

$Q$ bed.- No isopach maps of the coal and interburden were drawn for the $Q$ bed because drill-hole data were not available; however, the interburden between the $Q$ and $R$ beds suggests that the $Q$ bed may be correlative with the Rogers bed (p1. 3).

Rogers bed. - The Rogers bed is the uppermost coal bed in the area. It is at approximately the same horizon as the $Q$ bed and is about $105 \mathrm{ft}$ above the $\mathrm{R}$ bed ( $\mathrm{pl}$. 3). Its maximum data point thickness is $17.1 \mathrm{ft}$ at the outcrop in sec. 15, T. 13 N., R. 47 E. Data show that in most of the area the Rogers bed is split. The parting attains a thickness of $22 \mathrm{ft}$ in drill-hole US-74106 located in sec. 4, T. 12 N., R. 46 E. The coal thins abruptly northwestward from the southwest corner of sec. 15, T. $13 \mathrm{~N} .$, R. $47 \mathrm{E}$.

\section{REFERENCES}

Collier; A. J., and Knechtel, M. M., 1939, The coal resources of McCone County, Montana: U.S. Geological Survey Bulletin 905, 80 p.

Denson, N. M., and Gill, J. R., 1965, Uranium-bearing lignite and carbonaceous shale in the southwestern part of the Williston basin--A regional study, with a section on Heavy minerals in Cretaceous and Tertiary rocks associated with uranium occurrence, by W. A. Chisholm: U.S. Geological Survey Professional Paper 463, 75 p.

Matson, R. E., 1970, Preliminary report, strippable coal resources, McCone County, Montana: Montana Bureau of Mines and Geology Bulletin 78, $13 \mathrm{p}$.

McKay, E. J., and Mason, F. W., 1975a, Geology and coal sections, Morehouse Creek quadrangle, Montana: U.S. Geological Survey Miscellaneous Field Studies Map MF-724, scale 1:24,000. 
McKay, E. J., and Mason, F. W., 1975b, Geology and coal sections, Twin Buttes quadrangle, Montana: U.S. Geological Survey Miscellaneous Field Studies Map MF-725, scale 1:24,000.

U.S. Geological Survey, 1970, The National atlas of the United States of America: $417 \mathrm{p}$.

U.S. Geological Survey and Montana Bureau of Mines and Geology, 1978, Geophysical logs for Dawson, Garfield, McCone, and Prairie Counties, Montana, chapter D of Preliminary report of 1977 coal drilling in eastern Montana and northeastern Wyoming: U.S. Geological Survey Open-File Report 77-721-D.

Wincentsen, Herbert, 1978, Preliminary study of the coal deposits in the Circle area, McCone, Dawson, and Garfield Counties, Montana: U.S. Geological Survey Open-File Report 78-367, 11 p., 8 pls., 1 fig., 1 table. 